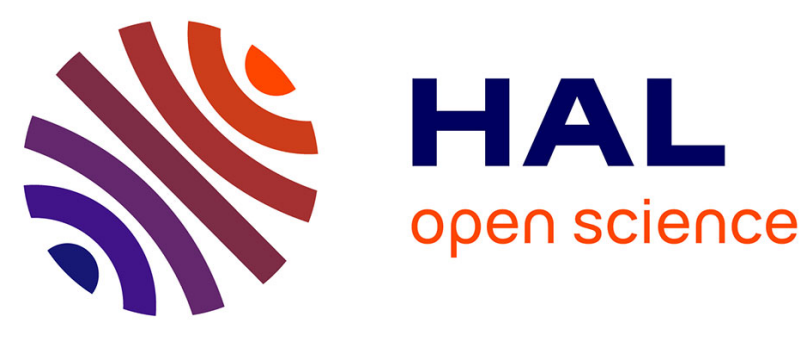

\title{
The human fibrinolytic system is a target for the staphylococcal metalloprotease aureolysin
}

Nathalie Beaufort, Piotr Wojciechowski, Christian P Sommerhoff, Grzegorz Szmyd, Grzegorz Dubin, Sigrun Eick, Josef Kellermann, Manfred Schmitt, Jan Potempa, Viktor Magdolen

\section{To cite this version:}

Nathalie Beaufort, Piotr Wojciechowski, Christian P Sommerhoff, Grzegorz Szmyd, Grzegorz Dubin, et al.. The human fibrinolytic system is a target for the staphylococcal metalloprotease aureolysin. Biochemical Journal, 2008, 410 (1), pp.157-165. 10.1042/BJ20070650 . hal-00478804

\section{HAL Id: hal-00478804 https://hal.science/hal-00478804}

Submitted on 30 Apr 2010

HAL is a multi-disciplinary open access archive for the deposit and dissemination of scientific research documents, whether they are published or not. The documents may come from teaching and research institutions in France or abroad, or from public or private research centers.
L'archive ouverte pluridisciplinaire HAL, est destinée au dépôt et à la diffusion de documents scientifiques de niveau recherche, publiés ou non, émanant des établissements d'enseignement et de recherche français ou étrangers, des laboratoires publics ou privés. 


\section{THE HUMAN FIBRINOLYTIC SYSTEM IS A TARGET FOR THE STAPHYLOCOCCAL METALLOPROTEASE AUREOLYSIN}

Nathalie Beaufort ${ }^{*}$, Piotr Wojciechowski ${ }^{*}{ }^{\dagger}$, Christian P. Sommerhoff*, Grzegorz Szmyd ${ }^{\dagger}$, Grzegorz Dubin ${ }^{\dagger}$, Sigrun Eick ${ }^{\S}$, Josef Kellermann", Manfred Schmitt ${ }^{*}$, Jan Potempa ${ }^{\dagger}$, Viktor Magdolen ${ }^{*}, 1$

*Department of Obstetrics and Gynecology, Technical University of Munich, Ismaninger Str. 22, D-81675 Munich, Germany;

${ }^{\dagger}$ Department of Microbiology, Faculty of Biochemistry, Biophysics and Biotechnology, Jagiellonian University, ul. Gronostajowa 7, 30-387, Krakow, Poland;

${ }^{\ddagger}$ Department of Clinical Chemistry and Clinical Biochemistry, Ludwig-MaximiliansUniversity, Nußbaumstr. 20, D-80336 Munich, Germany;

${ }^{\S}$ Department of Medical Microbiology, University Hospital of Jena, Semmelweisstr. 4, D07740 Jena, Germany;

"Max Planck Institute of Biochemistry, Martinsried, Klopferspitz 18, D-82152, Germany

Running Title: Aureolysin activates the fibrinolytic system

Keywords: proteolysis, Staphylococcus aureus, aureolysin, urokinase, staphylokinase, infection

\section{Footnotes}

${ }^{1}$ To who correspondence should be addressed: Viktor Magdolen, KliFo der Frauenklinik, TU München, Klinikum rechts der Isar, Ismaninger Str. 22, D-81675 Munich, Germany; Tel: (49)8941402493; Fax: (49)8941407410; E-mail: viktor@magdolen.de

Abbreviations: $\alpha_{2}$-AP, $\alpha_{2}$-antiplasmin; CM, conditioned medium; PAI-1, plasminogen activator inhibitor, SAK, staphylokinase; uPA, urokinase- tissue-type plasminogen activator 


\section{SYNOPSIS}

The major opportunistic pathogen Staphylococcus aureus utilizes the human fibrinolytic system for invasion and spread via plasmin(ogen) binding and non-proteolytic activation. Because $S$. aureus secretes several proteases recently proposed as virulence factors, we explored whether these enzymes could add to the activation of the host's fibrinolytic system.

Exposure of human pro-urokinase (pro-uPA) to conditioned growth media from staphylococcal reference strains results in an EDTA-sensitive conversion of the single-chain zymogen into its two-chain active form, an activity not observed in an aureolysin-deficient strain. Using purified aureolysin, we verified the capacity of this thermolysin-like metalloprotease to activate pro-uPA, with a $2.6 \times 10^{3} \mathrm{M}^{-1} \mathrm{~s}^{-1}$ catalytic efficiency. Moreover, activation also occurs in the presence of human plasma, as well as in conditioned growth media from clinical isolates. Finally, we establish that aureolysin (i) converts plasminogen into angiostatin and mini-plasminogen, the latter retaining its capacity to be activated by uPA and to hydrolyze fibrin, (ii) degrades the plasminogen activator inhibitor-1, and (iii) abrogates the inhibitory activity of $\alpha_{2}$-antiplasmin.

Altogether, we propose that, in parallel to the staphylokinase-dependent activation of plasminogen, aureolysin may contribute significantly to the activation of the fibrinolytic system by $S$. aureus, and thus may promote bacterial spread and invasion. 


\section{INTRODUCTION}

The plasminogen activation system comprises the serine protease zymogen plasminogen, its two proteolytic activators, urokinase- and tissue-type plasminogen activator (uPA and tPA, respectively), the major plasminogen activator inhibitor (PAI-1), and the plasmin inhibitor $\alpha_{2-}$ antiplasmin $\left(\alpha_{2}\right.$-AP) $[1,2]$. Once activated, plasmin displays a broad-spectrum trypsin-like enzymatic activity towards a number of substrates including fibrin, extracellular matrix components, basement membrane proteins and matrix metalloproteases. Significantly, plasmin also targets and activates its own activators, uPA and tPA, thus providing the system with a remarkable capacity for auto-amplification. The fibrinolytic system is involved in a variety of (patho)physiological processes including reproduction, embryogenesis, vascular homeostasis, inflammation, wound healing, as well as malignancies [2-4].

A large body of evidence indicates that some bacteria are capable of utilizing this otherwise tightly regulated proteolytic system, thereby promoting their spread and invasion, both through overexpression of its components, surface expression of plasmin(ogen) binding sites, activation of the zymogens, and/or inactivation of the protease inhibitors [5, 6]. Among these microorganisms, a remarkable example is represented by the Gram-positive bacterium Staphylococcus aureus, which enhances uPA production by mammalian cells, expresses lysine-rich binding sites for plasmin(ogen), and secretes the non-proteolytic plasminogen activator staphylokinase (SAK) [7-11]. S. aureus is an opportunistic human pathogen that colonizes numerous tissues and organs and can lead to a variety of benign to severe and often fatal disorders, including local and systemic infections, as well as toxic syndromes $[12,13]$. Moreover, this bacterium represents the worldwide leading cause of nosocomial infections and has an alarming capacity to develop resistance to antibiotics, demanding for a better knowledge of its pathobiology [14, 15].

Among the array of secreted staphylococcal factors, a number of proteases, including the serine proteases V8 (SspA/V8) and SplA to F, the cysteine proteases staphopain A and B (ScpA, SspB) and the metalloprotease aureolysin, have recently attracted attention ass potential virulence factors [16]. Aureolysin is a neutral, calcium-stabilized, zinc-dependant metalloprotease and belongs to the superfamily of M4, or thermolysin-like, endopeptidases [17]. Most, if not all, staphylococcal strains display a functional gene encoding for aureolysin [18], which is synthesized and secreted throughout the bacterial growth cycle [19]. Regarding its presumed targets, aureolysin activates the precursor of the bacterial V8 protease and cleaves staphylococcal surface-associated proteins (i.e., fibronectin-binding protein, protein A, clumping factor B), a property which is thought to support the transition from an adherent 
to an invasive phenotype [16, 20-22]. It also degrades human proteins including (i) immunoglobulins, (ii) the cathelicidin-derived antimicrobial peptide, LL-37, and (iii), the serpin-type plasma protease inhibitors $\alpha_{1}$-antichymotrypsin and $\alpha_{1}$-proteinase inhibitor, thereby potentially promoting bacterial escape from the host immune system, as well as uncontrolled proteolysis, leading to host tissue destruction [16, 23]. Altogether, it is thus tempting to speculate that aureolysin might display kee functions during host colonization, infection and invasion.

We now report that $S$. aureus reference and clinical strains are capable of converting the zymogen pro-uPA into its active form, a feature mediated by aureolysin. Interestingly, we demonstrate that aureolysin also targets other components of the plasminogen activation system, including plasminogen, PAI-1 and $\alpha_{2}$-AP. We thus propose that the activation of the host's fibrinolytic system by this metalloprotease might be an alternative mechanism to SAK expression, contributing to bacterial spread and invasion.

\section{EXPERIMENTAL}

\section{Materials}

Human Glu-plasminogen and plasmin, purified from plasma, and human two-chain active urokinase (uPA, 100,000 IU/mg), purified from urine, were from Sigma-Aldrich (Saint-Louis, MO), Chromogenix/Haemochrom Diagnostica (Essen, Germany) and ProSpec-Tany TechnoGene (Rehovot, Israel), respectively. Recombinant human pro-uPA, expressed in $E$. coli, was a kind gift from A.G. Saunders (Grünenthal, Aachen, Germany). Recombinant human PAI-1, expressed in E. coli, was produced and purified as previously reported [24]. Human $\alpha_{2}$-AP, purified from plasma, was a kind gift from J.J. Enghild (University of Aarhus, Denmark [25]). Aureolysin was purified from conditioned growth medium of the staphylococcal reference strain $\mathrm{V} 8-\mathrm{BC} 10$, according to the procedure initially described by Drapeau [26]. The enzyme purity was evaluated by sodium dodecylsulfate-polyacrylamide gel electrophoresis (SDS-PAGE) and the protein concentration was determined using a bicinchoninic acid kit (BCA, Sigma-Aldrich), with bovine serum albumin (Sigma-Aldrich) as a standard. Aureolysin, which was found to be in its active form, as judged by $\alpha_{2}$ macroglobulin titration, was stored at $-20^{\circ} \mathrm{C}$ as a $0.7 \mathrm{mg} / \mathrm{ml}$ (i.e., $21 \mu \mathrm{M}$ ) stock solution. Protease inhibitors were from Sigma-Aldrich.

The chromogenic plasmin substrate D-Val-Leu-Lys-paranitroanilide (pNA) (DVLK-902) was from Molecular Innovations (Southfield, MI, USA), the chromogenic uPA substrates TosGly-Pro-Arg-pNA (L-1480) and Bz- $\beta$-Ala-Gly-Arg-pNA (Pefachrome uPA) from Bachem 
(Bubendorf, Switzerland) and Loxo GmbH (Dossenheim, Germany), respectively, and the fluorogenic uPA substrate Boc-Leu-Gly-Arg-7-amido-4-methylcoumarin from Bachem. A rabbit polyclonal $\mathrm{Ab}$ directed to human plasminogen was from Dako (Glostrup, Denmark). A chicken polyclonal $\mathrm{Ab}$ directed to human $\mathrm{UPA}$ and strongly reacting with the $\mathrm{A}$-chain was a kind gift from N. Grebenchtchikov (University Medical Center Nijmegen, The Netherlands [27]). Horseradish peroxidase (HRP)-conjugated Abs against rabbit or chicken IgG were from Dianova (Hambourg, Germany) and Sigma-Aldrich, respectively.

\section{Bacterial strains and collection of conditioned growth media}

The following staphylococcal bacterial strains were used: Newman (NTCC 8178); 8325-4 (NTCC 8325); 8325-4 aur , corresponding to the strain 8325-4 with an isogene knockout of the gene encoding for aureolysin [20]; V8-BC10 [26]; a collection of nine clinical isolates (i.e., strains $\mathrm{n}^{\circ} 1,12,38,46,59,68,100,101$ and 103).

For collection of conditioned growth media (CM), bacteria were grown in trypticase soy broth medium (TSB, Sigma-Aldrich) for $10 \mathrm{~h}$ at $37^{\circ} \mathrm{C}$ with shaking until cells had reached the stationary growth phase. Bacterial cultures were then centrifuged for $20 \mathrm{~min}$ at $14,000 \mathrm{~g}$ at $4^{\circ} \mathrm{C}$ and the supernatants were collected and stored at $-20{ }^{\circ} \mathrm{C}$ before further use.

\section{PCR analysis}

Bacteria were lysed in a buffer containing $20 \mathrm{mM}$ Tris, 2\% Triton X-100, 2 mM EDTA, pH 8.0 , in the presence of $2.5 \mathrm{U}$ lysostaphine (Sigma-Aldrich), for $30 \mathrm{~min}$ at $37^{\circ} \mathrm{C}$ before genomic DNA extraction using the Genomic Mini kit (A\&A Biotechnology, Gdynia, Poland) according to the manufacturer's instructions. PCR amplification was performed using $0.5 \mathrm{U}$ of Taq DNA polymerase (Fermentas, Vilnius, Lithuania) and the following primers: 5'GTGAGGAAATTTTCAAGATATGC3', 5'CCACGCCTACTTCATTCCATGC3' (forward and reverse primers for aureolysin gene detection, respectively, IBB PAN, Warsaw, Poland), resulting in a 321 bp PCR product. The strains 8325-4 and 8325- 4 aur were used as positive and negative controls, respectively. 


\section{Aureolysin gelatin zymography}

Detection of aureolysin-related proteolytic activity was performed as previously reported [20]. Briefly, purified aureolysin (50 ng) or CM from clinical strains $(10 \mu \mathrm{l})$ were treated for $1.5 \mathrm{~h}$ at $37^{\circ} \mathrm{C}$ with $5 \%(\mathrm{w} / \mathrm{v}) \mathrm{SDS}$, prior to SDS-PAGE on $12 \%$ gels containing $0.2 \%(\mathrm{w} / \mathrm{v})$ gelatin. After electrophoresis, gels were washed twice in 2.5\% Triton X-100 and developed overnight in a $0.2 \mathrm{M}$ Tris, $\mathrm{pH} 7.8$ buffer containing $5 \mathrm{mM} \mathrm{CaCl}_{2}$ and $2 \mathrm{mM}$ of the $\mathrm{V} 8$ protease inhibitor 3,4-dichloroisocoumarin. Alternatively, the metalloprotease-related proteolytic activity was neutralized in the samples and in the development buffer by addition of $10 \mathrm{mM}$ EDTA instead of $\mathrm{CaCl}_{2}$. Gels were finally stained with amido black.

\section{Exposure of pro-uPA or plasminogen to $\mathrm{CM}$}

pro-uPA or plasminogen were adjusted to $200 \mu \mathrm{g} / \mathrm{ml}$ in CM diluted $1 / 2(\mathrm{v} / \mathrm{v})$ in a $100 \mathrm{mM}$ Tris, $100 \mathrm{mM} \mathrm{NaCl}, \mathrm{pH} 7.5$ (Tris/ $\mathrm{NaCl}$ ) buffer, and reaction continued for $5 \mathrm{~h}$ at $37^{\circ} \mathrm{C}$. Alternatively, incubation was carried out in the presence of protease inhibitors as indicated in the legend to Figure 1. Samples were frozen before preparation for SDS-PAGE or proteolytic activity measurement.

\section{Exposure of pro-uPA, plasminogen, PAI-1 or $\alpha_{2}$-AP to purified aureolysin} pro-uPA, plasminogen, PAI-1 or $\alpha_{2}-\mathrm{AP}$, adjusted to $20 \mu \mathrm{g} / \mathrm{ml}$ in a Tris/ $\mathrm{NaCl}$ buffer containing $5 \mathrm{mM} \mathrm{CaCl} 2$ (Tris/ $\mathrm{NaCl} / \mathrm{CaCl}_{2}$ ), were either mixed with aureolysin in the range 2.25 - $45 \mathrm{nM}$ (i.e., enzyme substrate, $\mathrm{E} / \mathrm{S}$, molar ratios varying from $1 / 100$ to $1 / 8$ ) for 1,5 or $24 \mathrm{~h}$ at $37^{\circ} \mathrm{C}$, or left untreated as control. To inhibit aureolysin proteolytic activity, $\mathrm{CaCl}_{2}$ was omitted and replaced by $5 \mathrm{mM}$ of EDTA in the reaction mixture. Samples were then frozen before preparation for SDS-PAGE or proteolytic activity measurement.

For experiments performed in plasma-derived buffer, human plasma from a healthy volunteer was collected according to standard procedures and diluted to $5 \%$ in a Tris/ $/ \mathrm{NaCl} / \mathrm{CaCl}_{2}$ buffer containing $10 \mu \mathrm{M}$ of the plasmin inhibitor aprotinin in order to prevent pro-uPA activation by traces of active plasmin. Exposure of pro-uPA to aureolysin was then performed exactly as described above.

\section{Activity measurement of human proteases}

Samples were placed in a 96-well plate and adjusted to a $160 \mu \mathrm{l}$ final volume in a $100 \mathrm{mM}$ Tris, $0.05 \%$ Tween-20, 0.01\% BSA, pH 7.5 buffer, (for DVLK-902 and L-1480), or in a 50 $\mathrm{mM}$ Tris, $150 \mathrm{mM} \mathrm{NaCl}$, pH 8.0 buffer (for Pefachrome) in the presence of $0.19 \mathrm{mM}$ DVLK- 
902, or $0.13 \mathrm{mM} \mathrm{L}-1480$ or Pefachrome. The release of pNA at $37^{\circ} \mathrm{C}$ was then monitored at $405 \mathrm{~nm}$ in a spectrophotometer (SLT-Labinstruments, Grödig, Austria) over a 30-min time period.

To assay the inhibitory activity of aureolysin-treated PAI-1 or $\alpha_{2}$-AP the serpins were allowed to interact with their target proteases uPA (for PAI-1) or plasmin (for $\alpha_{2}$-AP) for 30 min at room temperature before measurement of the remaining proteolytic activity of the mixture.

\section{Determination of the kinetic parameters of pro-uPA activation}

Aureolysin $(1 \mathrm{nM})$ or plasmin $(0.01 \mathrm{nM})$, which had been standardized by active-site titration using $p$-nitrophenyl- $p^{\prime}$-guanidinobenzoate [28], were incubated with varying concentrations of pro-uPA $(0-10 \mu \mathrm{M})$ in a $50 \mathrm{mM}$ HEPES, $150 \mathrm{mM} \mathrm{NaCl}, 0.01 \%$ Azide, $0.01 \%$ Triton $\mathrm{X}-100$, pH 7.4 buffer. Zymogen activation was followed by recording the release of 7-amino-4methylcoumarin (AMC) generated by cleavage of the reporter substrate Boc-Leu-Gly-Arg-7amino-4-methylcoumarin $(20 \mu \mathrm{M})$ by activated $\mathrm{UPA}$. In each experiment, the specific activity of UPA towards the reporter substrate was determined using active-site-titrated uPA ( $0-10$ $\mathrm{nM}$ ) under the same conditions; cleavage by pro-uPA (or contaminating uPA), aureolysin and plasmin was negligible. Data were recorded every 30 seconds for 30 minutes using a HTS 7000 Bio Assay Reader (PerkinElmer, Rodgau-Jügesheim, Germany), with excitation and emission wavelength of 360 and $465 \mathrm{~nm}$, respectively.

The time-dependent increase of AMC was fitted to a modification of an integrated rate equation describing a coupled zymogen activation and reporter reaction initially used to analyze the activation of plasminogen $[29,30]$ :

$$
\mathrm{AMC}_{(\mathrm{t})}=0.5 \cdot \mathrm{a}_{\mathrm{rs}} \cdot \mathrm{V}_{\mathrm{z}} \cdot\left(\mathrm{t}-\mathrm{t}_{0}\right)^{2}+\mathrm{AMC}_{0},
$$

where $\mathrm{AMC}_{(\mathrm{t})}$ and $\mathrm{AMC}_{0}$ are the concentrations of $\mathrm{AMC}$ measured at time $\mathrm{t}$ and baseline, respectively, $t_{0}$ the delay between the start of the reaction and the first measurement, $V_{z}$ the velocity of zymogen activation, and $\mathrm{a}_{\mathrm{rs}}$ the specific activity of uPA towards the reporter substrate. The zymogen activation velocities $\mathrm{V}_{\mathrm{z}}$ at different pro-uPA concentrations calculated from two different experiments were subsequently fitted to the Michaelis-Menten equation to obtain the kinetic parameters $\mathrm{K}_{\mathrm{m}}, \mathrm{k}_{\mathrm{cat}}$ and $\mathrm{k}_{\mathrm{cat}} / \mathrm{K}_{\mathrm{m}}$. Both curve fitting steps were performed with proFit (Quantum Soft, Uetikon am See, Switzerland) using a LevenbergMarquardt algorithm. 


\section{Protein chemical analysis and immunoblotting}

Proteins (500 ng per well for silver staining or 100, 200 or $2000 \mathrm{ng}$ per well for immunoblotting) were reduced in the presence of $2 \%(\mathrm{w} / \mathrm{v}) \operatorname{SDS}$ and $5 \%(\mathrm{v} / \mathrm{v}) 2$ mercaptoethanol for $5 \mathrm{~min}$ at $95{ }^{\circ} \mathrm{C}$, followed by SDS-PAGE. Separated proteins were then either silver-stained according to standard procedures, or transferred onto polyvinylidene fluoride membranes (PVDF, Pall, Dreieich, Germany) prior to immunoblotting. After blocking with dried skimmed milk, membranes were probed with the primary antibody, as indicated in the figure legends, and bound antibodies were detected by a HRP-coupled secondary antibody (dilution: 1/10 000) followed by a chemiluminescent reaction (ECL, Amersham Biosciences, Little Chalfont, UK).

For aminoterminal microsequencing, pro-uPA, plasminogen or $\alpha_{2}-\mathrm{AP}$ were adjusted to 400 $\mu \mathrm{g} / \mathrm{ml}$ in a Tris $/ \mathrm{NaCl} / \mathrm{CaCl}_{2}$ buffer and exposed to aureolysin in an $\mathrm{E} / \mathrm{S}$ molar ratio of $1 / 100$, or left untreated as control, for 1 to $2 \mathrm{~h}$ at $37^{\circ} \mathrm{C}$. Proteins were then solubilized and reduced as described above before SDS-PAGE separation on 12\% gels (or 16.5\% Tris/Tricine gels for $\alpha_{2}$-AP-related low molecular weight fragment) prior to transfer onto PVDF membranes. Protein bands visualized by Coomassie staining were finally excised and subjected to Edman degradation (pulse liquid phase sequencer, Procise 492, Applied Biosystems, Foster City, CA). 


\section{RESULTS}

\section{Activation of human pro-uPA by a secreted staphylococcal metalloprotease}

To study the interactions of extracellular proteases secreted by $S$. aureus with the human fibrinolytic system, we first exposed plasminogen and pro-uPA to CM from staphylococcal reference strains, and subsequently analyzed the reaction mixture by immunoblotting and protease activity measurement.

Exposure of plasminogen (molecular weight $\approx 97 \mathrm{kDa}$ ) to $\mathrm{CM}$ from the strains $8325-4$ and V8-BC10 (the latter strain being well characterized for its high protease expression levels [26]), for $5 \mathrm{~h}$ resulted in the processing of the zymogen into several molecular species, which were clearly distinct from those generated by exposure of plasminogen to its activator uPA (data not shown). Protease activity measurement confirmed the absence of detectable plasminogen activation by the bacterial secreted factors (data not shown). Conversely, a $5 \mathrm{~h}$ exposure of pro-uPA (molecular weight $\approx 49 \mathrm{kDa}$ ) to $\mathrm{CM}$ from the above mentioned strains, resulted in the processing of the zymogen into two major $\approx 28$ and $20 \mathrm{kDa}$ molecular species, which were similar to the B- and A-chain generated by exposure of pro-uPA to its activator plasmin (Figure 1A and C). While processing of pro-uPA was incomplete when the zymogen was exposed to $\mathrm{CM}$ from strain $8325-4$, it was nearly complete after exposure to $\mathrm{CM}$ from strain V8-BC10. This latter observation was also confirmed by protease activity measurement

\section{(Figure 1B and D).}

To identify the secreted staphylococcal enzyme(s) responsible for pro-uPA activation, we next exposed pro-uPA to both CM in the presence of an array of protease inhibitors (Figure 1). Western blotting and protease activity measurement indicated that, in contrast to inhibitors of serine, aspartate, and cysteine proteases, a cocktail of protease inhibitors as well as EDTA efficiently inhibited pro-uPA activation by bacterial CM (Figure 1A to D). Among the proteolytic enzymes secreted by $S$. aureus, aureolysin is the only known metalloprotease [16, 20], therefore, this neutral thermolysin-like protease was the candidate to cause the EDTAsensitive proteolytic activation of pro-uPA by staphylococcal CM. To investigate this hypothesis, we next collected CM from a strain deficient for the gene encoding for aureolysin (i.e., 8325-4 aur [20]) and used it for incubation with pro-uPA. In marked contrast to that from the parental 8325-4 strain, CM from this aureolysin-deficient strain was indeed unable to activate pro-uPA (Figure 1E and F). 


\section{Proteolytic activation of human pro-uPA by purified aureolysin}

To further prove aureolysin as the pro-uPA activating enzyme secreted by $S$. aureus, we exposed pro-uPA to concentrations of purified aureolysin in the range $4.5-45 \mathrm{nM}$ (i.e., $\mathrm{E} / \mathrm{S}$ molar ratios from $1 / 100$ to $1 / 10$ ). Incubation for 1 to $24 \mathrm{~h}$ prior to SDS-PAGE of the reaction mixture revealed a conversion of the zymogen into a major $\approx 28 \mathrm{kDa}$ species and into minor $\approx$ $20 \mathrm{kDa}$ products (Figure 2A). Processing of pro-uPA, which was already detectable after $1 \mathrm{~h}$ exposure to a protease concentration as low as $4.5 \mathrm{nM}$, was time- and concentrationdependent and was completely inhibited in the presence of EDTA. As illustrated in Figure 2B, aminoterminal microsequencing of the $28 \mathrm{kDa}$ fragment, which remained stable and accumulated over time, demonstrated that it is generated by hydrolysis of the Lys ${ }^{158}-\mathrm{Ile}^{159}$ peptide bond and thus corresponds to the B-chain of uPA. The lower molecular weight species were identified as degradation products of the A-chain, resulting from cleavage between the growth factor and kringle domains and from further cleavage within the former domain. Exposure of pro-uPA to various concentrations of aureolysin for different periods of time followed by protease activity measurement confirmed the activation of the zymogen by the bacterial metalloprotease, occurring as soon as $1 \mathrm{~h}$ of exposure to $4.5 \mathrm{nM}$ aureolysin and reaching a maximum after $5 \mathrm{~h}$ of exposure to $45 \mathrm{nM}$ enzyme (Figure 2C). It is important to note that, when assayed under similar $\mathrm{E} / \mathrm{S}$ molar ratios, none of the other purified staphylococcal proteases tested, including the serine proteases V8, SplA and SplB, as well as the cysteine proteases staphopain A (ScpA) and B (SspB), were able to activate pro-uPA (data not shown).

To characterize the efficiency of pro-uPA activation by aureolysin, we subsequently determined the kinetic parameters (Figure 2D) which were as follows: $\mathrm{k}_{\text {cat }} 0.3 \pm 0.1 \mathrm{~s}^{-1}, \mathrm{~K}_{\mathrm{m}}$ $100 \pm 28 \mu \mathrm{M}$ (extrapolated), and $\mathrm{k}_{\text {cat }} / \mathrm{K}_{\mathrm{m}} 2.6 \pm 0.2 \times 10^{3} \mathrm{~s}^{-1} \mathrm{M}^{-1}$, whereas the catalytic efficiency of human plasmin to activate pro-uPA, determined in parallel under identical conditions, was about 300 fold higher $\left(\mathrm{k}_{\mathrm{cat}} 2.0 \pm 0.03 \mathrm{~s}^{-1}, \mathrm{~K}_{\mathrm{m}} 2.3 \pm 0.1 \mu \mathrm{M}, \mathrm{k}_{\mathrm{cat}} / \mathrm{K}_{\mathrm{m}} 7.7 \pm 0.2 \mathrm{x}\right.$ $\left.10^{5} \mathrm{~s}^{-1} \mathrm{M}^{-1}\right)$.

Finally, to mimic S. aureus-induced vascular leakage, we exposed pro-uPA to 4.5 to $45 \mathrm{nM}$ aureolysin in the presence of 5\% human plasma for $5 \mathrm{~h}$. Western blotting analysis of the resulting proteins again revealed an EDTA-sensitive conversion of the pro-enzyme into its Aand B-chain (Figure 2E). Along with this, an increased proteolytic activity of the reaction mixture towards a uPA-specific chromogenic substrate was detectable for $45 \mathrm{nM}$ aureolysin (Figure 2F), although pro-uPA activation was clearly less efficient than that observed in the absence of plasma (compare Figure $2 \mathrm{~A}$ and $\mathrm{C}$ to Figure $\mathbf{2 E}$ and $\mathbf{F}$ ). This probably reflects 
the presence of protease inhibitors, including the potent aureolysin inhibitor $\alpha_{2}$ macroglobulin, and of competitive aureolysin substrates [16, 31-34], in normal human plasma.

\section{pro-uPA activation by clinical staphylococcal isolates}

We next explored the relevance of the aureolysin-dependent pro-uPA activation using CM from clinical $S$. aureus isolates. For this, clinical strains were collected from an asymptomatic nasal carrier and from 8 patients suffering from various local and systemic staphylococcal infections representative for the variety of tissues that are colonized or infected by $S$. aureus (Table 1). PCR analysis of these strains indicated that all 9 strains were positive for the gene encoding aureolysin.

pro-uPA was exposed for $5 \mathrm{~h}$ to $\mathrm{CM}$ from these strains before Western blotting analysis and protease activity measurement were performed (Figure 3A and B). A marked (i.e., in the range of 50\%) conversion of pro-uPA into its active form was noted with CM from one of the clinical isolates (i.e., strain $\mathrm{n}^{\circ} 1$ ), and a smaller but significant (i.e., at least $10 \%$ ) activation of the zymogen was also observed with CM from 5 other strains (i.e., strains $n^{\circ} 12,48,59,68$ and 100). Significantly, pro-uPA activation was completely inhibited in the presence of EDTA, suggesting a predominant participation of aureolysin. To strengthen this assumption, we assayed the CM from these strains for aureolysin-related proteolytic activity. As depicted in Figure 3C and in Table 1, gelatin zymography experiments indeed confirmed that aureolysin activity present in these CM correlates to their capacity to activate pro-uPA.

\section{Hydrolysis of plasminogen, PAI-1 and $\alpha_{2}$-AP by purified aureolysin}

To determine whether aureolysin also targets other components of the plasminogen activation system, we next assessed its impact both on the zymogen plasminogen and on the regulatory serpins PAI-1 and $\alpha_{2}-\mathrm{AP}$.

Exposure of plasminogen to aureolysin concentrations in the range $2.25-22.5 \mathrm{nM}$ (i.e., $\mathrm{E} / \mathrm{S}$ molar ratios from $1 / 100$ to $1 / 10$ ) for 1 to $24 \mathrm{~h}$ resulted in an EDTA-sensitive conversion of the zymogen into truncated molecular species of $\approx 67.5,61$ and $39.5 \mathrm{kDa}$, as evaluated by SDSPAGE analysis (Figure 4A). According to their molecular weight and aminoterminal sequences (Figure 4A and D, respectively) these fragments correspond to previously reported carbohydrate variants of angiostatin, encompassing the kringle domains 1 to 4 (molecular weight $\approx 61$ and $67.5 \mathrm{kDa}$, aminoterminus Lys-Val-Tyr-Leu/Val-Tyr-Leu-Ser) [35] and to mini-plasminogen, encompassing the kringle domain 5 and the catalytic domain of the serine 
protease (molecular weight $\approx 39.5 \mathrm{kDa}$, aminoterminus Val-Val-Ala-Pro). According to protease activity measurement, aureolysin was indeed unable to activate plasminogen into plasmin (in fact, none of the other purified staphylococcal proteases mentioned above including V8, SplA, SplB, ScpA and SspB, was able to do so, data not shown). It is of note that aureolysin did not destroy the zymogen, as the cleavage products could subsequently be activated by uPA, either purified, or as generated via exposure of pro-uPA to the bacterial enzyme (data not shown). Moreover, aureolysin-generated mini-plasmin, although devoid of its lysine-binding sites, was still endowed with fibrinolytic capacities, as evaluated on a fibrin plate (data not shown).

Exposure of PAI-1 to aureolysin at similar E/S molar ratios and time periods resulted in degradation of the inhibitor (Figure 4B). To assess the impact of aureolysin/PAI-1 interaction on the capacity of the serpin to inhibit UPA, we first incubated aureolysin-processed PAI-1 with sub-saturating concentrations of uPA, thus allowing the formation of irreversible protease/inhibitor complexes, before monitoring the ability of the resulting mixture to hydrolyse a selective trypsin-like protease chromogenic substrate. This indicated that the proteolytic degradation of PAI-1 by aureolysin was associated with a drastic decrease in its capacity to inhibit uPA, down to $7 \pm 16 \%$ of the inhibitory activity of the control PAI-1 (set as $100 \%$ ), after $1 \mathrm{~h}$ of exposure to $45 \mathrm{nM}$ aureolysin (Figure 4E).

Similarly exposure of $\alpha_{2}$-AP to aureolysin led to the processing of the inhibitor. A slight decrease of $\alpha_{2}$-AP molecular weight (i.e., from $\approx 63.5$ to $62 \mathrm{kDa}$ ) was detectable as soon as 1 $\mathrm{h}$ of exposure to $40 \mathrm{nM}$ aureolysin and was followed by a time-dependent disappearance of the latter truncated species, concomitant with the appearance of $\approx 53 \mathrm{kDa}$ (Figure 4C) and 10 $\mathrm{kDa}$ (Tris/Tricine gel, not shown) products. Aminoterminal microsequencing of both $\approx 62$ and $53 \mathrm{kDa}$ species revealed a new Leu-Gly-Asn-Gln aminoterminus, reflecting hydrolysis of the Lys $^{12}$-Leu $^{13}$ peptide bond, while the $\approx 10.5 \mathrm{kDa}$ species, which is bearing a Ile-Ala-Met-Ser aminoterminus, is produced by hydrolysis of the $\operatorname{Ser}^{359}-\mathrm{Ile}^{360}$ peptide bond. Interestingly, the latter cleavage occurs in the vicinity of the inhibitor reactive bonds (i.e., $\mathrm{Arg}^{364}-\mathrm{Met}^{365}$ and $\mathrm{Met}^{365}-\mathrm{Ser}^{366}$, as reported for $\alpha_{2}$-AP cleavage by other bacterial metalloproteases [36]. Measurement of the residual inhibitory activity of aureolysin-processed $\alpha_{2}$-AP towards plasmin indicated that while the initial aminoterminal hydrolysis of $\alpha_{2}$-AP by aureolysin does not affect the serpin inhibitory activity, cleavage within its exposed reactive loop is associated to a decreased inhibitory activity, down to $23 \pm 11 \%$ of the control inhibitor, after a $24 \mathrm{~h}$ exposure to $40 \mathrm{nM}$ aureolysin (Figure 4F). 


\section{DISCUSSION}

During the course of infection, bacterial proteases, including those secreted by $S$. aureus, are endowed with decisive functions that are e.g. related to regulation of microbial adherence to host cells and tissues, dampening of the host immune response, as well as tissue destruction and bacterial invasiveness $[16,37,38]$. Here we report that the staphylococcal thermolysinlike metalloprotease aureolysin is capable of activating the human fibrinolytic system through processing of pro-uPA into its active form uPA, and inactivation of the plasmin and plasminogen activator inhibitors $\alpha_{2}$-AP and PAI-1, respectively. Moreover, aureolysin converts the zymogen plasminogen into angiostatin and mini-plasminogen, thus modulating its functions. Although aureolysin's specificity has not been analyzed yet, thermolysin-like enzymes have been demonstrated to preferentially hydrolyze peptide bonds bearing a hydrophobic residue at the $\mathrm{P} 1^{\prime}$ position [38]. The description of limited endoproteolysis of fibrinolytic system-related proteins by aureolysin and the identification of the cleavage sites within human macromolecules such as pro-uPA (i.e., $\mathrm{Tyr}^{24}-\mathrm{Phe}^{25}, \mathrm{Lys}^{36}-\mathrm{Phe}^{37}$ and Lys ${ }^{158}$ -

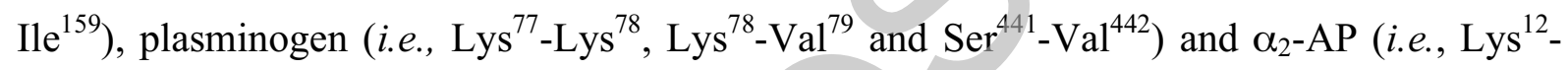
$\mathrm{Leu}^{13}$ and $\mathrm{Ser}^{359}-\mathrm{Ile}^{360}$ ), are thus in line with this specificity and provide new insights in the putative biological substrates of this staphylococcal protease.

It is of note that besides plasmin, a number proteases have also been identified that can convert pro-uPA into an active enzyme. Compared to the catalytic efficiency of human plasmin $\left(\mathrm{k}_{\mathrm{cat}} / \mathrm{K}_{\mathrm{m}}=1.9-7.7 \times 10^{5} \mathrm{~s}^{-1} \mathrm{M}^{-1}\right.$, our results and [39]), however, those reported for other enzymes are lower, ranging from $2.4 \times 10^{3}$ to $4.8 \times 10^{5} \mathrm{~s}^{-1} \mathrm{M}^{-1}$ for mast cell tryptase and hepsin [39, 40], respectively. With $2.6 \times 10^{3} \mathrm{~s}^{-1} \mathrm{M}^{-1}$, the specificity constant $\mathrm{k}_{\mathrm{cat}} / \mathrm{K}_{\mathrm{m}}$ of aureolysin is thus at the lower end of this range, but equivalent to those reported for acknowledged pro-uPA activators e.g. for mast cell tryptase and glandular kallikrein $(2.4 \mathrm{x}$ $10^{3}$ and $3.3 \times 10^{3} \mathrm{~s}^{-1} \mathrm{M}^{-1}$ respectively) [40, 41]. Similarly, although aureolysin displays a low affinity for pro-uPA ( $\mathrm{K}_{\mathrm{m}} \sim 100 \mu \mathrm{M}$ as compared to $2.3 \mu \mathrm{M}$ for plasmin), it is comparable to that determined for tryptase $\left(\mathrm{K}_{\mathrm{m}}=34 \mu \mathrm{M}\right)$ [40]. Still, due to this relatively low affinity, aureolysin appears not to be a very efficient pro-uPA activator, particularly at low pro-uPA concentrations such as those in the circulation (1-2 ng/ml). However, pro-uPA concentration increases dramatically in inflammation and infection. Accordingly, up to $0.2 \mathrm{mg} / \mathrm{ml}$ of prouPA ( $\sim 4 \mu \mathrm{M}$, which is the concentration used in our assays) have been measured in lung homogenates of mice infected with $S$. pneumoniae, suggesting that locally, pro-uPA concentration may even be higher [42]. Such conditions would favor activation of pro-uPA by aureolysin. We, therefore, suggest that after colonization by $S$. aureus and during subsequent 
inflammation, aureolysin may initiate the auto-amplified proteolytic cascade involving uPA, plasmin and MMP in vivo [2]. This assumption is supported by our observations that (i) aureolysin, either purified or secreted by clinical isolates of $S$. aureus, indeed activates the human zymogen, and (ii) pro-uPA activation by aureolysin occurs in the presence of human plasma. Along with this, other thermolysin-like bacterial proteases, including thermolysin itself, as well as bacillolysin, both secreted by non-pathogenic bacteria (i.e., Bacillus thermoproteolyticus and Bacillus megaterium, respectively), have also been demonstrated to activate pro-uPA $[35,43]$.

Activation of the human fibrinolytic system by bacteria is presumed to support bacterial dissemination and invasiveness (i) through the release of large amounts of bacteria sequestrated within fibrin deposits, thus leading to the propagation of infection, and (ii), through hydrolysis of the extracellular matrix and basement membranes, as well as through proteolytic disruption of intercellular contacts, thus provoking tissue destruction $[2,6]$. Apart from these well-known features, activation of the plasminogen-derived matrilytic system might also damage tissues via induction of cell apoptosis, and via amplification of a deleterious immune response, either through the release of matrix-entrapped proinflammatory cytokines and chemokines, or through the activation of cellular effectors $[2,44$, 45]. Among the array of bacterial factors reported to interact with the plasminogen activation system, the staphylococcal plasminogen-activator SAK provides a significant example [5, 11]. SAK is a nonproteolytic bacterial protein which forms a stoechiometric complex with plasminogen, resulting in a change of conformation of the latter and facilitating its activation by minute amounts of plasmin, whereas SAK-bound plasmin is protected from interaction with its inhibitor $\alpha_{2}$-AP $[5,11]$. SAK, which has focused major interest because of its putative therapeutic use as a thrombolytic agent $[5,11]$, is thus considered to be a notable bacterial virulence factor. However, by contrast to the widely distributed aur gene, only 70 to $75 \%$ of staphylococcal strains are positive for the sak gene $[11,46]$. Moreover, clinical staphylococcal strains produce only negligible amounts of SAK [47]. We thus assume that through proteolytic activation of pro-uPA, aureolysin might provide a complementary mechanism, or even, for the SAK-deficient strains, an alternative pathway, to the extensively studied, nonproteolytic SAK-dependent activation of the human fibrinolytic system by $S$. aureus. The fact that aureolysin also disrupts the major plasma protease inhibitors of this system (i.e., $\alpha_{2}-$ $\mathrm{AP}$ and PAI-1) further supports this hypothesis, which now demands to be confirmed within an in vivo infection model. In parallel, as previously for other bacterial metalloprotease, aureolysin processes plasminogen into angiostatin and mini-plasminogen [35, 48]. On the one 
hand, aureolysin-generated mini-plasminogen retains its capacity to be further activated by uPA and by aureolysin-generated uPA, and the resulting mini-plasmin is endowed with fibrinolytic capacities (data not shown). On the other hand, the well-known anti-angiogenic factor angiostatin was recently reported to be an efficient inhibitor of leukocytes recruitment in vitro [49]. This feature may thus represent a novel aspect of the dampening of the host defence machinery by $S$. aureus-secreted proteases.

Finally, direct pro-uPA activation might well be a feature shared by other disease-related microorganisms expressing thermolysin-like proteases (i.e., Pseudomonas aeruginosa, Listeria monocytogenes, Legionella pneumophila, Vibrio cholerae, Bacillus anthracis) [38]. We thus consider that uPA inhibitors are worth to be tested in infectious contexts. Indeed, it is of note that activation of the fibrinolytic system by malignant tumor cells, including uPA overexpression and activation, have been considered for long to represent a key element in the capacity of these cells to proliferate, invade and disseminate [3]. As a consequence, the array of therapeutic tools interfering with the plasminogen activation system, and including synthetic uPA inhibitors, which have been designed in the context of cancer disease [3,50], might also be of therapeutic interest to prevent bacterial propagation and invasiveness. 


\section{ACKNOWLEDGEMENTS}

This work was supported by fellowships from the Bayerische Forschungsstiftung and from the Alexander von Humboldt foundation (to N.B.), and by an Erasmus student mobility grant (to P.W.). The authors are indebted with Dr. Dominique Pidard (Inserm U.698, C.H.U. Xavier-Bichat, Paris, France) for critical reading of the manuscript and with Dr. Jan J. Enghild (Department of Molecular and Structural Biology, University of Aarhus, Aarhus, Denmark) for providing $\alpha_{2}$-AP. The authors express gratitude to Sabine Streicher (Department of Clinical Chemistry and Clinical Biochemistry, Ludwig-MaximiliansUniversity, Munich, Germany) for excellent technical assistance. 


\section{REFERENCES}

1 Lijnen, H. R. (2001) Elements of the fibrinolytic system. Ann. N. Y. Acad. Sci. 936, 226-236

2 Ellis, V. (2003) Plasminogen activation at the cell surface. Curr. Top. Dev. Biol. 54, 263-312

3 Danø, K., Behrendt, N., Høyer-Hansen, G., Johnsen, M., Lund, L. R., Ploug, M. and Rømer, J. (2005) Plasminogen activation and cancer. Thromb. Haemost. 93, 676-681

4 Castellino, F. J. and Ploplis, V. A. (2005) Structure and function of the plasminogen/plasmin system. Thromb. Haemost. 93, 647-654

5 Coleman, J. L. and Benach, J. L. (1999) Use of the plasminogen activation system by microorganisms. J. Lab. Clin. Med. 134, 567-576

6 Lähteenmaki, K., Edelman, S. and Korhonen, T. K. (2005) Bacterial metastasis: the host plasminogen system in bacterial invasion. Trends Microbiol. 13, 79-85

7 Kuusela, P. and Saksela, O. (1990) Binding and activation of plasminogen at the surface of Staphylococcus aureus. Increase in affinity after conversion to the Lys form of the ligand. Eur. J. Biochem. 193, 759-765

8 Christner, R. B. and Boyle, M. D. (1996) Role of staphylokinase in the acquisition of plasmin(ogen)-dependent enzymatic activity by staphylococci. J. Infect. Dis. 173, 104112

9 Zavizion, B., White, J. H. and Bramley, A. J. (1997) Staphylococcus aureus stimulates urokinase-type plasminogen activator expression by bovine mammary cells. J. Infect. Dis. 176, 1637-1640

10 Mölkänen, T., Tyynelä, J., Helin, J., Kalkkinen, N. and Kuusela, P. (2002) Enhanced activation of bound plasminogen on Staphylococcus aureus by staphylokinase. FEBS Lett. 517, 72-78

11 Bokarewa, M. I., Jin, T. and Tarkowski, A. (2006) Staphylococcus aureus: Staphylokinase. Int. J. Biochem. Cell. Biol. 38, 504-509

12 Lowy, F. D. (1998) Staphylococcus aureus infections. N. Engl. J. Med. 339, 520-532

13 Murray, R. J. (2005) Recognition and management of Staphylococcus aureus toxinmediated disease. Intern. Med. J. 35, S106-119

14 Diekema, D. J., Pfaller, M. A., Schmitz, F. J., Smayevsky, J., Bell, J., Jones, R. N. and Beach, M. (2001) Survey of infections due to Staphylococcus species: frequency of occurrence and antimicrobial susceptibility of isolates collected in the United States, 
Canada, Latin America, Europe, and the Western Pacific region for the SENTRY Antimicrobial Surveillance Program, 1997-1999. Clin. Infect. Dis. 32, S114-132

15 Lindsay, J. A. and Holden, M. T. (2004) Staphylococcus aureus: superbug, super genome? Trends Microbiol. 12, 378-385

16 Dubin, G. (2002) Extracellular proteases of Staphylococcus spp. Biol. Chem. 383, 1075-1086

17 Banbula, A., Potempa, J., Travis, J., Fernandez-Catalan, C., Mann, K., Huber, R., Bode, W. and Medrano, F. (1998) Amino-acid sequence and three-dimensional structure of the Staphylococcus aureus metalloproteinase at 1.72 A resolution. Structure 6, 1185-1193

18 Sabat, A., Kosowska, K., Poulsen, K., Kasprowicz, A., Sekowska, A., van Den Burg, B., Travis, J. and Potempa, J. (2000) Two allelic forms of the aureolysin gene (aur) within Staphylococcus aureus. Infect. Immun. 68, 973-976

19 Arvidson, S. (1973) Studies on extracellular proteolytic enzymes from Staphylococcus aureus. II. Isolation and characterization of an EDTA-sensitive protease. Biochim. Biophys. Acta 302, 149-157

20 Shaw, L., Golonka, E., Potempa, J. and Foster, S. J. (2004) The role and regulation of the extracellular proteases of Staphylococcus aureus. Microbiology 150, 217-228

21 McGavin, M. J., Zahradka, C., Rice, K. and Scott, J. E. (1997) Modification of the Staphylococcus aureus fibronectin binding phenotype by V8 protease. Infect. Immun. 65, 2621-2628

22 McAleese, F. M., Walsh, E. J., Sieprawska, M., Potempa, J. and Foster, T. J. (2001) Loss of clumping factor B fibrinogen binding activity by Staphylococcus aureus involves cessation of transcription, shedding and cleavage by metalloprotease. J. Biol. Chem. 276, 29969-29978

23 Sieprawska-Lupa, M., Mydel, P., Krawczyk, K., Wojcik, K., Puklo, M., Lupa, B., Suder, P., Silberring, J., Reed, M., Pohl, J., Shafer, W., McAleese, F., Foster, T., Travis, J. and Potempa, J. (2004) Degradation of human antimicrobial peptide LL-37 by Staphylococcus aureus-derived proteinases. Antimicrob. Agents Chemother. 48, $4673-4679$

24 Arroyo De Prada, N., Schroeck, F., Sinner, E. K., Muehlenweg, B., Twellmeyer, J., Sperl, S., Wilhelm, O. G., Schmitt, M. and Magdolen, V. (2002) Interaction of plasminogen activator inhibitor type-1 (PAI-1) with vitronectin. Eur. J. Biochem. 269, 184-192 
25 Enghild, J. J., Valnickova, Z., Thogersen, I. B., Pizzo, S. V. and Salvesen, G. (1993) An examination of the inhibitory mechanism of serpins by analysing the interaction of trypsin and chymotrypsin with alpha 2-antiplasmin. Biochem. J. 291, 933-938

26 Drapeau, G. R. (1978) Role of metalloprotease in activation of the precursor of staphylococcal protease. J. Bacteriol. 136, 607-613

27 Grebenchtchikov, N., Sweep, C. G., Geurts-Moespot, A., Piffanelli, A., Foekens, J. A. and Benraad, T. J. (2002) An ELISA avoiding interference by heterophilic antibodies in the measurement of components of the plasminogen activation system in blood. J. Immunol. Methods 268, 219-231

28 Chase, T., Jr. and Shaw, E. (1970) Titration of trypsin, plasmin, and thrombin with pnitrophenyl-p-guanidinobenzoate $\mathrm{HCl}$. In Methods in Enzymology (Perlmann G.E., and Lorand L., ed.), pp 20-27, New York

29 Liu, J. N. and Gurewich, V. (1993) The kinetics of plasminogen activation by thrombin-cleaved pro-urokinase and promotion of its activity by fibrin fragment E-2 and by tissue plasminogen activator. Blood $\mathbf{8 1}, 980-987$

30 Castro, M. J., Kingston, I. B. and Anderson, S. (1995) A spectrophotometric assay for the determination of the catalytic efficiency of plasminogen activators using a slowly hydrolyzed plasmin substrate. Anal. Biochem. 226, 225-231

31 Prokesova, L., Potuznikova, B., Potempa, J., Zikan, J., Rad1, J., Porwit-Bobr, Z. and John, C. (1995) Cleavage of human immunoglobulins by proteinase from Staphylococcus aureus. Adv. Exp. Med. Biol. 371, 613-616

32 Wegrzynowicz, Z., Heczko, P. B., Drapeau, G. R., Jeljaszewicz, J. and Pulverer, G. (1980) Prothrombin activation by a metalloprotease from Staphylococcus aureus. J. Clin. Microbiol. 12, 138-139

33 Potempa, J., Watorek, W. and Travis, J. (1986) The inactivation of human plasma alpha 1-proteinase inhibitor by proteinases from Staphylococcus aureus. J. Biol. Chem. 261, 14330-14334

34 Potempa, J., Fedak, D., Dubin, A., Mast, A. and Travis, J. (1991) Proteolytic inactivation of alpha-1-anti-chymotrypsin. Sites of cleavage and generation of chemotactic activity. J. Biol. Chem. 266, 21482-21487

35 Narasaki, R., Kuribayashi, H., Shimizu, K., Imamura, D., Sato, T. and Hasumi, K. (2005) Bacillolysin MA, a novel bacterial metalloproteinase that produces angiostatinlike fragments from plasminogen and activates protease zymogens in the coagulation and fibrinolysis systems. J. Biol. Chem. 280, 14278-14287 
36 Kress, L. F. (1986) Inactivation of human plasma serine proteinase inhibitors (serpins) by limited proteolysis of the reactive site loop with snake venom and bacterial metalloproteinases. J. Cell. Biochem. 32, 51-58

37 Travis, J., Potempa, J. and Maeda, H. (1995) Are bacterial proteinases pathogenic factors? Trends Microbiol. 3, 405-407

38 Supuran, C. T., Scozzafava, A. and Clare, B. W. (2002) Bacterial protease inhibitors. Med. Res. Rev. 22, 329-372

39 Moran, P., Li, W., Fan, B., Vij, R., Eigenbrot, C. and Kirchhofer, D. (2006) Prourokinase-type plasminogen activator is a substrate for hepsin. J. Biol. Chem. 281, 30439-30446

40 Stack, M. S. and Johnson, D. A. (1994) Human mast cell tryptase activates singlechain urinary-type plasminogen activator (pro-urokinase). J. Biol. Chem. 269, 94169419

41 List, K., Jensen, O. N., Bugge, T. H., Lund, L. R., Ploug, M., Danø, K. and Behrendt, N. (2000) Plasminogen-independent initiation of the pro-urokinase activation cascade in vivo. Activation of pro-urokinase by glandular kallikrein (mGK-6) in plasminogendeficient mice. Biochemistry 39, 508-515

42 Rijneveld, A. W., Levi, M., Florquin, S., Speelman, P., Carmeliet, P. and van Der Poll, T. (2002) Urokinase receptor is necessary for adequate host defense against pneumococcal pneumonia. J. Immunol. 168, 3507-3511

43 Marcotte, P. A. and Henkin, J. (1993) Characterization of the activation of prourokinase by thermolysin. Biochim. Biophys. Acta 1161, 105-112

44 Meilhac, O., Ho-Tin-Noe, B., Houard, X., Philippe, M., Michel, J. B. and AnglesCano, E. (2003) Pericellular plasmin induces smooth muscle cell anoikis. Faseb J. 17, 1301-1303

45 Syrovets, T. and Simmet, T. (2004) Novel aspects and new roles for the serine protease plasmin. Cell. Mol. Life. Sci. 61, 873-885

46 van Wame1, W. J., Rooijakkers, S. H., Ruyken, M., van Kessel, K. P. and van Strijp, J. A. (2006) The innate immune modulators staphylococcal complement inhibitor and chemotaxis inhibitory protein of Staphylococcus aureus are located on betahemolysin-converting bacteriophages. J. Bacteriol. 188, 1310-1315

47 Collen, D., Silence, K., Demarsin, E., De Mol, M. and Lijnen, H. R. (1992) Isolation and characterisation of natural and recombinant staphylokinase. Fibrinolysis 6, 203213 
48 Lijnen, H. R., Van Hoef, B., Ugwu, F., Collen, D. and Roelants, I. (2000) Specific proteolysis of human plasminogen by a $24 \mathrm{kDa}$ endopeptidase from a novel Chryseobacterium Sp. Biochemistry 39, 479-488

49 Chavakis, T., Athanasopoulos, A., Rhee, J. S., Orlova, V., Schmidt-Woll, T., Bierhaus, A., May, A. E., Celik, I., Nawroth, P. P. and Preissner, K. T. (2005) Angiostatin is a novel anti-inflammatory factor by inhibiting leukocyte recruitment. Blood 105, 1036-1043

50 Magdolen, V., Arroyo de Prada, N., Sperl, S., Muehlenweg, B., Luther, T., Wilhelm, O. G., Magdolen, U., Graeff, H., Reuning, U. and Schmitt, M. (2000) Natural and synthetic inhibitors of the tumor-associated serine protease urokinase-type plasminogen activator. Adv. Exp. Med. Biol. 477, 331-341 


\section{TABLES}

Table 1. Origin and characteristics of the staphylococcal clinical strains assayed for their capacity to activate human pro-uPA

\begin{tabular}{|c|c|c|c|c|}
\hline Strain n & Origin & $\begin{array}{c}\text { aur } \\
\text { gene }^{\mathbf{a}}\end{array}$ & $\begin{array}{c}\text { Aur-related } \\
\text { proteolytic } \\
\text { activity }^{\mathbf{b}}\end{array}$ & $\begin{array}{c}\text { Capacity to } \\
\text { activate }^{\text {pro-uPA }}\end{array}$ \\
\hline 1 & pneumonia & + & ++ & ++ \\
12 & nasal swab & + & + & + \\
38 & skin infection & + & - & - \\
46 & joint infection & + & ++ & + \\
59 & cystic fibrosis & + & + & + \\
68 & wound infection & + & + & + \\
100 & conjunctivitis & + & + & + \\
101 & sepsis & + & - & - \\
103 & sepsis & + & - & - \\
\hline
\end{tabular}

${ }^{\mathrm{a}}$ Clinical strains were tested for the presence of the (aur) gene, encoding for aureolysin (Aur), as described in the Experimental section. + refers to the presence of the $321 \mathrm{bp} \mathrm{PCR} \mathrm{product}$ corresponding to the aur gene.

${ }^{\mathrm{b}}$ Aur-related proteolytic activity displayed by $\mathrm{CM}$ was assayed by gelatin zymography as depicted in Figure 3.,+++ , and - refer to strong, medium and weak to no gelatinolytic activity, respectively.

${ }^{\mathrm{c}}$ The capacity of CM to activate human pro-uPA was tested through Western blotting and protease activity measurement as depicted in Figure 3.,,+++- and refer to strong, medium and week to non-detectable uPA activation, respectively. 


\section{FIGURE LEGENDS}

\section{Figure 1. A secreted staphylococcal metalloprotease activates pro-uPA}

The staphylococcal reference strains 8325-4, either wild-type (A and B) or aureolysindeficient (aur ${ }^{-}$) (E and F), and V8-BC10 (C and D) were cultivated to the stationary growth phase, before collection of CM. pro-uPA $(200 \mu \mathrm{g} / \mathrm{ml})$ was either exposed to CM diluted $1 / 2$, or to TSB medium, in the presence or absence of plasmin (Pm, $4 \mu \mathrm{g} / \mathrm{ml}, \mathrm{E} / \mathrm{S}$ molar ratio $1 / 100$ ), for $5 \mathrm{~h}$ at $37^{\circ} \mathrm{C}$. The following protease inhibitors were used: a commercial cocktail of protease inhibitors (cock, from Sigma); $5 \mathrm{mM}$ benzamidin (benza) or $10 \mu \mathrm{M}$ aprotinin (aprot), both serine protease inhibitors; $5 \mu \mathrm{M}$ pepstatin A (pepst), an aspartic protease inhibitor; 10 $\mu \mathrm{M}$ E-64, a cysteine protease inhibitor; 5mM EDTA, a metalloprotease inhibitor. (A, C, E) Proteins were subjected to SDS-PAGE under reducing conditions followed by immunoblotting using a chicken anti-uPA pAb strongly reactive with the A-chain of uPA (dilution 1/2,000). Panels included are representative of independent experiments, and arrows on the left hand side indicate the location of pro-uPA and of the A- and B-chain of uPA. (B, D, F) uPA proteolytic activity was measured by spectrophotometry using the selective chromogenic substrate L-1480. Histograms represent mean + SEM of 3 independent experiments. The proteolytic activity of purified uPA, used as an external positive control, is represented as a dotted $(0.2 \mu \mathrm{g})$ and a bold $(2 \mu \mathrm{g})$ line which correspond to 10 and $100 \%$ activation of the zymogen present in the assay, respectively. The intrinsic proteolytic activities of CM on L-1480 were found to be insignificant (B, D, F), and exposure of pro-uPA to TSB medium left the zymogen intact and inactive (A-F).

\section{Figure 2. Purified aureolysin activates pro-uPA}

(A and B) pro-uPA $(20 \mu \mathrm{g} / \mathrm{ml})$ was exposed to purified aureolysin (Aur) in E/S molar ratios ranging from $1 / 100$ to $1 / 10$ (i.e., 4.5 to $45 \mathrm{nM}$ Aur), or left untreated as control, for 1 to $24 \mathrm{~h}$ at $37^{\circ} \mathrm{C}$. Alternatively, $5 \mathrm{mM}$ EDTA were added to the reaction mixture to inhibit the proteolytic activity of Aur. (A) Proteins were subjected to SDS-PAGE under reducing conditions followed by silver staining. The depicted panel is representative of independent experiments, and arrows on the left-hand side indicate the location of pro-uPA and of the Aand B- chain of uPA. (B) Peptide bonds targeted by Aur within pro-uPA were determined by aminoterminal microsequencing (GFD: growth factor domain, K: kringle domain, C: catalytic domain). Dots indicate the location of the amino acid residues constituting the serine protease catalytic triad, while arrows indicate the position of cleavage sites. (C) uPA proteolytic activity was measured using the L-1480 chromogenic substrate which was found not to be 
cleaved by Aur (data not shown). Black (E/S 1/100) and grey (E/S 1/10) histograms represent mean + SEM of 3 independent experiments, and the proteolytic activity of purified uPA $(0.2$ $\mu \mathrm{g}$ ), corresponding to $100 \%$ of activation of the zymogen present in the assay, is represented as a bold line. (D) To determine the kinetic constants of the zymogen activation, pro-uPA (0$10 \mu \mathrm{M}$ ) was incubated with Aur or Pm in the presence of the fluorogenic uPA substrate BocLeu-Gly-Arg-7-amino-4-methylcoumarin, and the released 7-amino-4-methylcoumarin (AMC) was monitored spectrofluorimetrically over $30 \mathrm{~min}$. The mean velocities of pro-uPA activation by $1 \mathrm{nM}$ Aur (filled squares) or $0.01 \mathrm{nM}$ Pm (opened squares) calculated from two experiments are reploted as a function of zymogen concentration. The curves were generated by fitting the data to the Michaelis-Menten equation. (E and F) pro-uPA $(20 \mu \mathrm{g} / \mathrm{ml})$ was exposed to purified Aur in E/S molar ratios ranging from 1/100 to $1 / 10$ (i.e., 4.5 to $45 \mathrm{nM}$ Aur), or left untreated as control (NT), for $5 \mathrm{~h}$ at $37^{\circ} \mathrm{C}$ in a buffer containing $5 \%$ heparinized plasma and $10 \mu \mathrm{M}$ aprotinin in order to disable traces of active Pm. Alternatively, the proteolytic activity of Aur was blocked with $5 \mathrm{mM}$ EDTA added to the reaction mixture. (E) Proteins were subjected to SDS-PAGE under reducing conditions followed by immunoblotting using a chicken anti-uPA pAb strongly reacting with the A-chain of uPA (dilution 1/2,000). Panels included are representative of 3 independent experiments and arrows on the left-hand side indicate the location pro-uPA and of the A-and B-chain of uPA. (F) uPA proteolytic activity was measured by spectrophotometry using the uPA-specific chromogenic substrate Pefachrome. Histograms represent mean + SEM of 3 independent experiments. The proteolytic activity of purified uPA is represented as a dotted $(0.2 \mu \mathrm{g})$ and a bold $(2 \mu \mathrm{g})$ line, and corresponds to 10 and $100 \%$ activation of the zymogen present in the assay, respectively. The intrinsic proteolytic activity of plasma-derived buffer on Pefachrome was found to be insignificant (F), and exposure of pro-uPA to aprotinin-containing, plasmaderived buffer left the zymogen intact and inactive (E and F).

Figure 3. S. aureus clinical isolates secrete an EDTA-sensitive, pro-uPA activating factor Nine staphylococcal clinical strains $\left(\mathrm{n}^{\circ} 1,12,38,46,59,68,100,101\right.$ and 103) were cultivated to the stationary growth phase before collection of CM. pro-uPA (200 $\mu \mathrm{g} / \mathrm{ml})$, was either exposed to CM diluted $1 / 2$, or to TSB medium in the presence or absence of Pm (4 $\mu \mathrm{g} / \mathrm{ml}, \mathrm{E} / \mathrm{S} 1 / 100)$, for $5 \mathrm{~h}$ at $37^{\circ} \mathrm{C}$. Alternatively, the proteolytic activity of metalloproteases was neutralized by addition of $5 \mathrm{mM}$ EDTA in the reaction mixture. (A) Proteins were subjected to SDS-PAGE under reducing conditions followed by immunoblotting using a chicken anti-uPA pAb (dilution 1/2,000). Panels included are representative of independent 
experiments, and arrows on the left-hand side indicate the location of pro-uPA and of the Aand B-chain of uPA. (B) uPA proteolytic activity was measured by spectrophotometry using the chromogenic substrate L-1480. Histograms represent mean + SEM of 3 independent experiments. The proteolytic activity of purified uPA is represented as a dotted $(0.2 \mu \mathrm{g})$ and a bold $(2 \mu \mathrm{g})$ line which correspond to 10 and $100 \%$ activation of the zymogen present in the assay, respectively. The intrinsic proteolytic activity of CM on L-1480 was found to be insignificant (data not shown). (C) The proteolytic activity of purified Aur (50 ng) and CM from the clinical isolates $(20 \mu \mathrm{l})$ was visualized using gelatin zymography in the presence of $5 \mathrm{mM} \mathrm{CaCl} 2$ and $2 \mathrm{mM}$ of the V8 protease inhibitor 3,4-dichloroisocoumarin. The panel included is representative of independent assays. The arrow on the left-hand side indicates the location of Aur-related gelatinolytic areas, whereas asterisks indicate the location of Aurrelated shifted areas, which were both determined to be EDTA-sensitive (data not shown).

\section{Figure 4. Proteolysis of human plasminogen, PAI-1 and $\alpha_{2}$-AP by purified aureolysin}

(A, B, C) Plg, PAI-1, or $\alpha_{2}$-AP, all at a concentration of $20 \mu \mathrm{g} / \mathrm{ml}$, were exposed to purified Aur in the range 2.25 to $40 \mathrm{nM}$ (i.e., E/S molar ratios in the range 1/100 to 1/8), or left untreated as control, for 1 to $24 \mathrm{~h}$ at $37^{\circ} \mathrm{C}$. Alternatively, the proteolytic activity of Aur was blocked with $5 \mathrm{mM}$ EDTA added to the reaction mixture. Proteins were subjected to SDSPAGE under reducing conditions followed by silver staining. Panels included are representative of independent experiments, and arrows on the left-hand side indicate the location (A) of Plg and Plg-derived molecular species (from the top to the bottom: proteins of $\approx 67.5,61$ and $39.5 \mathrm{kDa}),(\mathbf{B})$ of PAI-1 $(\approx 43 \mathrm{kDa})$ or $(\mathbf{C})$, of $\alpha_{2}$-AP and $\alpha_{2}$-AP-derived molecular species (from the top to the bottom: proteins of $\approx 62$ and $53 \mathrm{kDa}$ ). (D) Peptide bonds targeted by Aur within Plg were determined by aminoterminal microsequencing (PAP: pre-activation peptide, K: kringle domain, C: catalytic domain). Dots indicate the location of amino acid residues constituting the serine protease catalytic triad, the black diamond indicates a N-linked glycosylation site, while arrows indicate the position of cleavage sites. (E and F) PAI- 1 or $\alpha_{2}$-AP were exposed, as described above, to 4.5, 22.5, or $45 \mathrm{nM}$ Aur (PAI$1)$, or to 4 or $40 \mathrm{nM}$ Aur ( $\alpha_{2}-\mathrm{AP}$, black and grey grey histograms, respectively), or left untreated as control, for $1 \mathrm{~h}$ (PAI-1), or for 1 to $24 \mathrm{~h}\left(\alpha_{2}-\mathrm{AP}\right)$ at $37^{\circ} \mathrm{C}$. Aur-processed serpins were then allowed to interact with subsaturating quantities of their respective protease targets, UPA and Pm, for $30 \mathrm{~min}$ at room temperature, before measurement of the residual proteolytic activity using the chromogenenic substrates L-1480 and DVLK-902, respectively. Results are expressed as a percentage of inhibitory activity, with $100 \%$ corresponding to that of the 
B Biochemical Journal Immediate Publication. Published on 31 Oct 2007 as manuscript BJ20070650

serpins unexposed to Aur. Histograms represent mean + SEM of 2 (E) to 3 (F) independent experiments. 


\section{FIGURES}
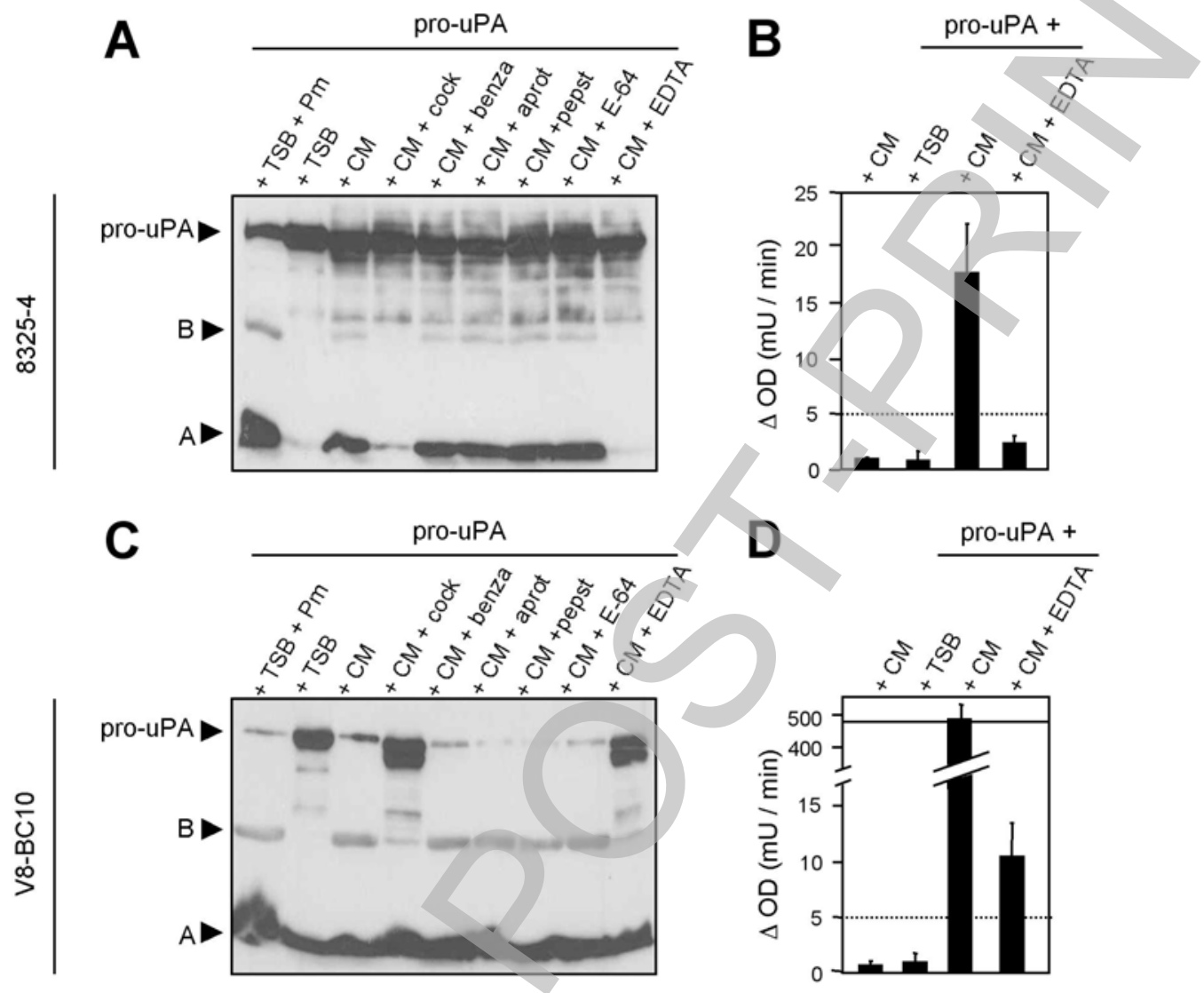

E
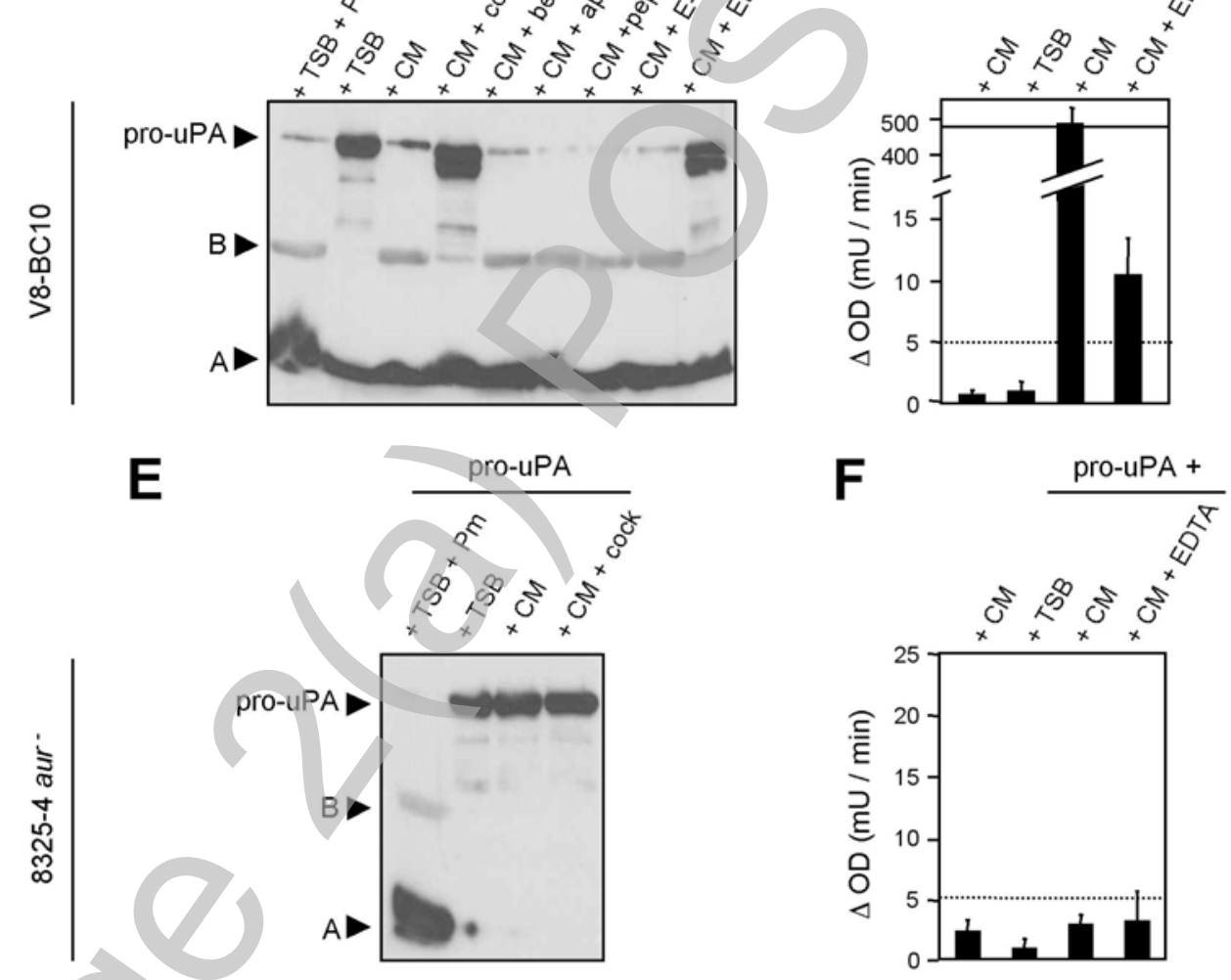

Figure 1 
A

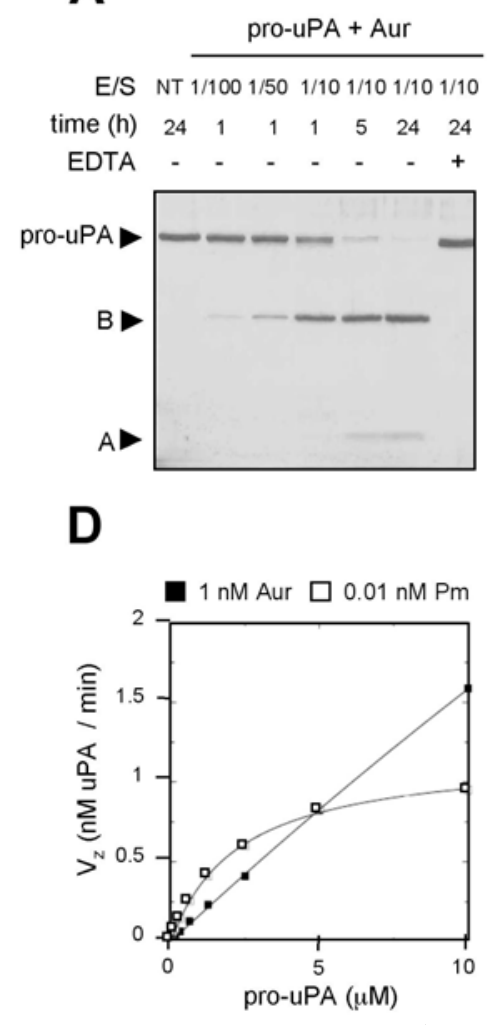

B

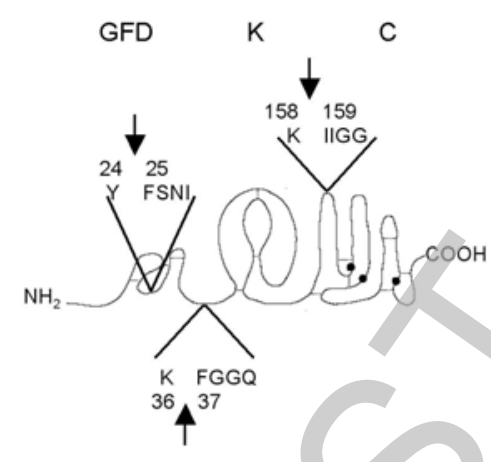

$\mathbf{E}$

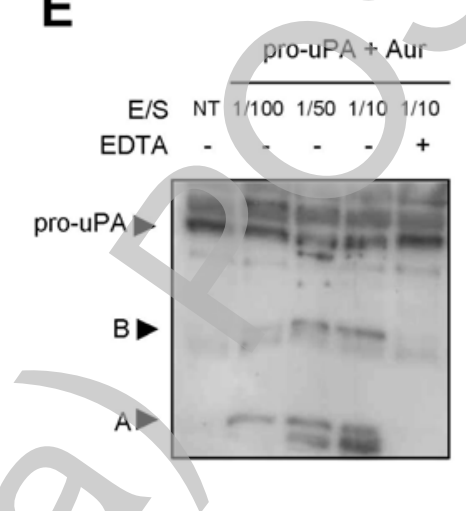

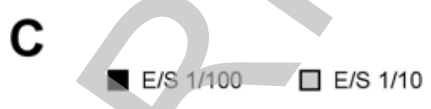

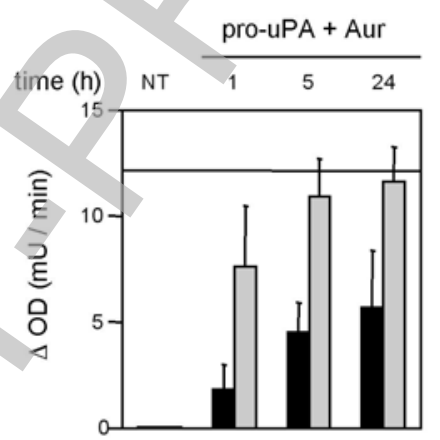

$\mathbf{F}$

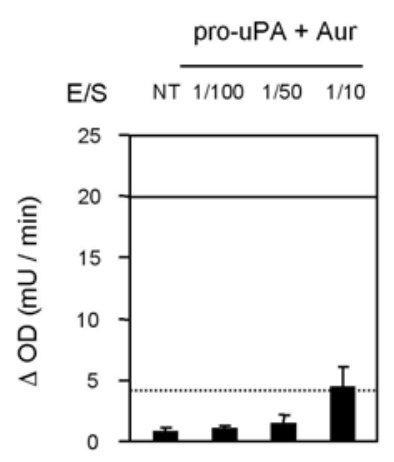

Figure 2 
Biochemical Journal Immediate Publication. Published on 31 Oct 2007 as manuscript BJ20070650

A

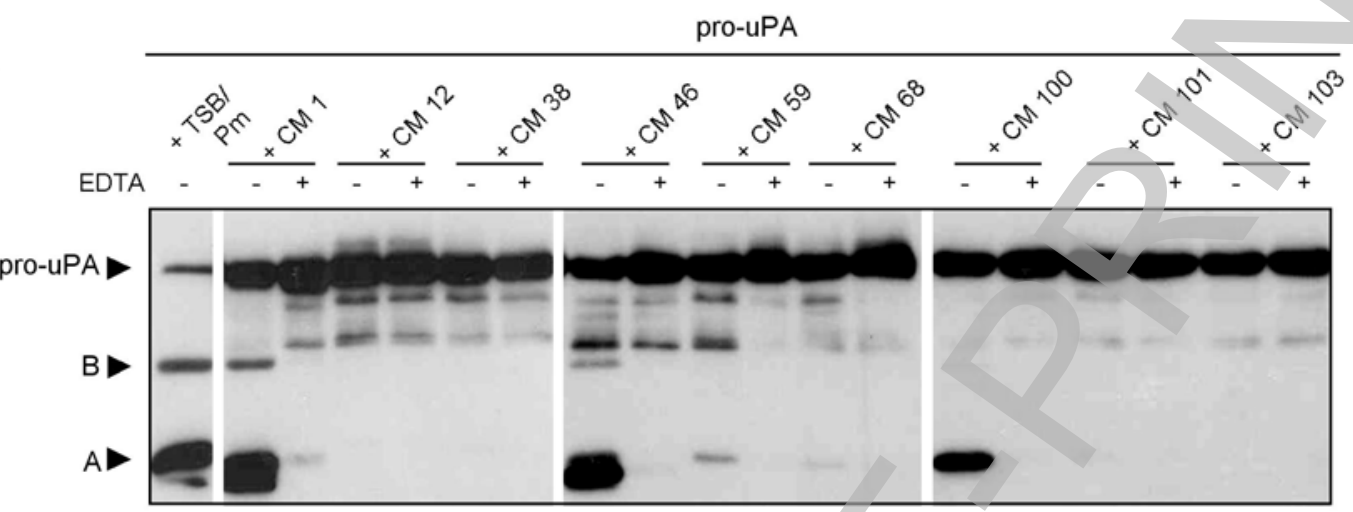

B
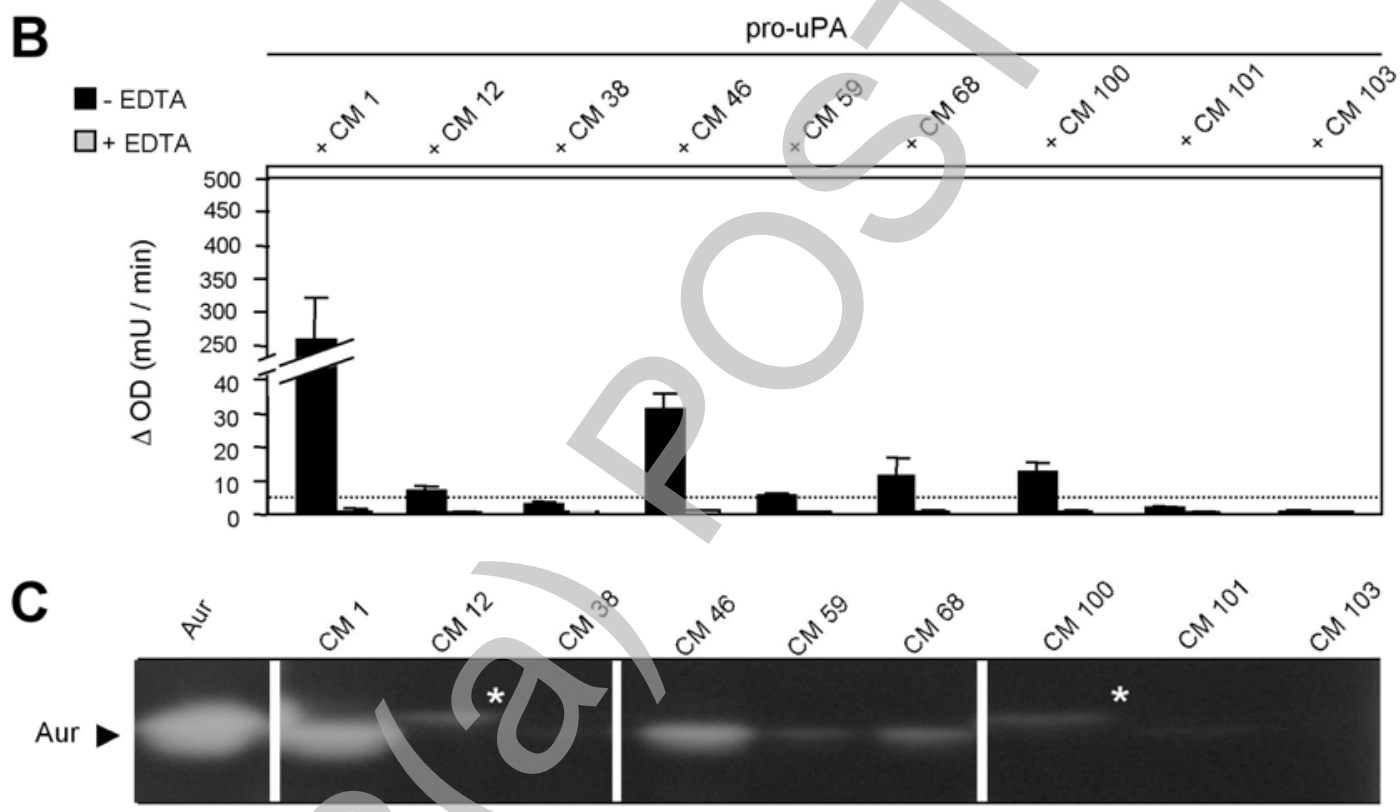

Figure 3

Licenced copy. Copying is not permitted, except with prior permission and as allowed by law. (C) 2007 The Authors Journal compilation (C) 2007 Biochemical Society 
A

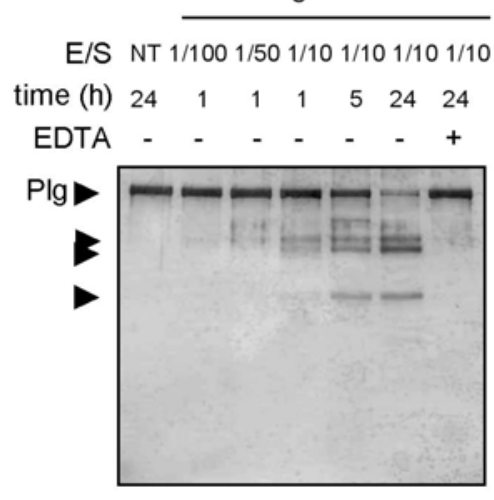

D

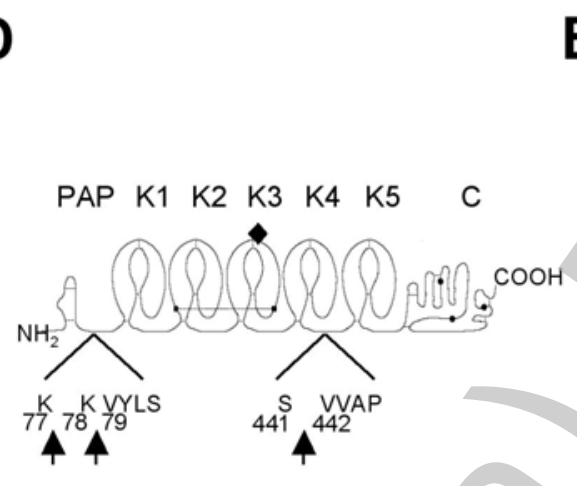

B
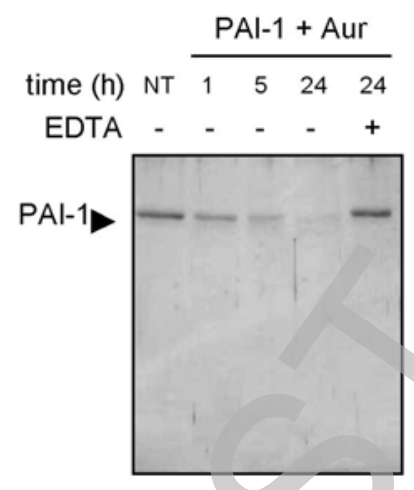

E

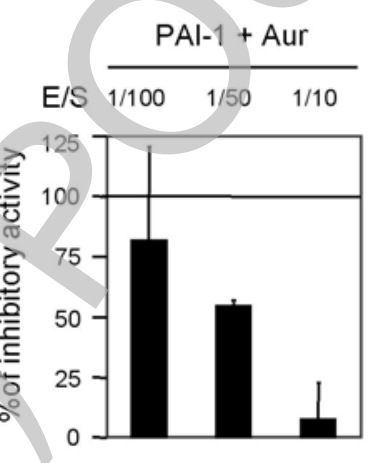

Figure 4
C

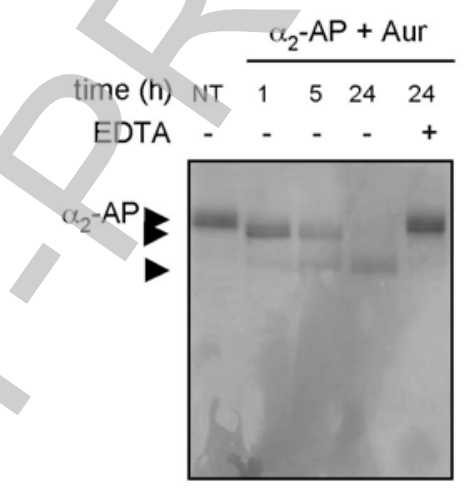

$\mathbf{F}$

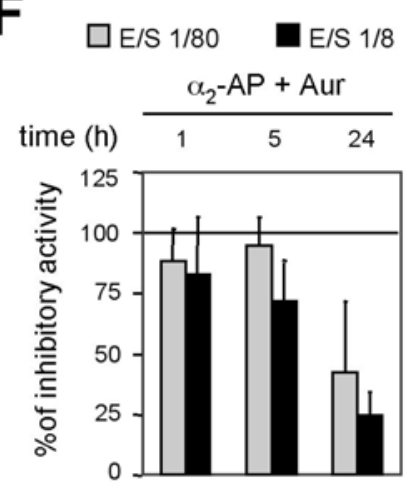

